\title{
AUTORADIOGRAPHIC LOCALIZATION OF ADENOSINE UPTAKE SITES IN RAT BRAIN USING $\left[{ }^{3} \mathrm{H}\right]$ NITROBENZYLTHIOINOSINE ${ }^{1}$
}

\author{
J. C. BISSERBE, J. PATEL, AND P. J. MARANGOS ${ }^{2}$ \\ Unit on Neurochemistry, Biological Psychiatry Branch, National Institute of Mental Health, Bethesda, Maryland 20205
}

Received June 12, 1984; Revised July 30, 1984; Accepted August 8, 1984

\begin{abstract}
The adenosine uptake site has been localized in rat brain by an in vitro light microscopic autoradiographic method, using $\left[{ }^{3} \mathrm{H}\right]$ nitrobenzylthioinosine $\left(\left[{ }^{3} \mathrm{H}\right] \mathrm{NBI}\right)$ as the probe. The binding characteristics of $\left[{ }^{3} \mathrm{H}\right] \mathrm{NBI}$ on slide-mounted sections are comparable to those seen in studies performed on brain homogenates. A very high density of uptake sites occurs in the nucleus tractus solitarius, in the superficial layer of the superior colliculus, in several thalamic nuclei, and also in geniculate body nuclei. A high density of sites are also observed in the nucleus accumbens, the caudate putamen, the dorsal tegmentum area, the substantia nigra, and the central gray. The localization of the adenosine uptake site in brain may provide information on the functional activity of the site and suggests the involvement of the adenosine system in the central regulation of cardiovascular function.
\end{abstract}

There is a growing body of evidence to suggest that adenosine acts as a neuromodulator in the CNS (for review, see Daly, 1983). In common with various classical neurotransmitters, adenosine is stored within nerve terminals and is released in a calcium-dependent manner from these structures when depolarized. The released pool of adenosine acts at specific receptors, causing a change in intracellular cyclic AMP (Van Calker et al., 1979) and/or calcium levels (Ribeiro, 1979). Two distinct adenosine receptors coupled to the adenylate cyclase have recently been identified (Van Calker et al., 1979; Cooper et al., 1980). They are the A-1 receptor, involved in the adenosinemediated inhibition of the cyclase activity, and the A-2 type, mediating the stimulation of adenylate cyclase. More recently, adenosine receptors have been identified by binding studies (Bruns et al., 1980; Patel et al., 1982). A specific adenosine receptor involved in the modulation of calcium fluxes has not yet been identified.

Like other classical neurotransmitters, a mechanism is present for the removal of adenosine from the synaptic cleft. This is achieved by reuptake involving an energy-dependent transport system (Shimizu et al., 1972; Kuroda and MacIlwain, 1974; Bender, 1980; Barberis et al., 1981). Deamination of adenosine by adenosine deaminase may also play a role in the inactivation of adenosine (Pull and MacIlwain, 1974; Arch and Newsholme, 1978). Previous studies have demonstrated that the adenosine uptake site can be labeled using $\left[{ }^{3} \mathrm{H}\right]$ nitrobenzylthioinosine $\left({ }^{3} \mathrm{H}\right] \mathrm{NBI}$ ), a potent inhibitor of adenosine uptake (Picard and Patterson, 1972; Jarvis and Young, 1980). Also, we have previously demonstrated the presence of $\left[{ }^{3} \mathrm{H}\right] \mathrm{NBI}$-binding sites in neuronal tissue and have shown that these sites are distinctly

\footnotetext{
${ }^{1}$ We are grateful to Sandra Coopersmith for the preparation of the manuscript. J. -C. B. is a Fellow of the French Ministry for Research (Direction Générale à la Recherche Scientifique et Technique).

${ }^{2}$ To whom correspondence should be sent, at Biological Psychiatry Branch, National Institute of Mental Health, Building 10, Room 3D48, Bethesda, MD 20205.
}

different from the adenosine A-1 and A-2 receptors (Marangos et al., 1982; Patel et al., 1982).

In the present report, using $\left[{ }^{3} \mathrm{H}\right] \mathrm{NBI}$, we have labeled adenosine uptake sites in rat brain slices and have visualized them by means of autoradiography. In this manner we were able to demonstrate the precise localization of $\left[{ }^{3} \mathrm{H}\right] \mathrm{NBI}-$ binding sites in the rat brain. A regional distribution comparison of $\left[{ }^{3} \mathrm{H}\right]$ NBI-binding sites and those of adenosine A-1 receptor is also presented.

\section{Materials and Methods}

The autoradiographic procedure involves incubating slide-mounted tissue sections with [ $\left.{ }^{3} \mathrm{II}\right] \mathrm{NBI}(16 \mathrm{Ci} / \mathrm{mol}$; Moravek Biochemicals) to label the binding sites and apposing tritium-sensitive film (LKB Ultrofilm). The details of this procedure have been reported previously (Herkenham and Pert, 1982). Male Sprague-Dawley rats (250 to 300 $\mathrm{gm})$ were decapitated, and the brains were removed quickly and frozen at $-40^{\circ} \mathrm{C}$ in 2 -methylbutane, then fixed onto a brass Microtome chuck with embedding media (Tissue Tek II, Lab Tek). Sections of $20 \mu \mathrm{m}$ were cut at $-20^{\circ} \mathrm{C}$ in an American Optical cryostat, thaw-mounted on gelatin-coated glass slides, and stored at $-20^{\circ} \mathrm{C}$ until needed. A set of intercalated sections was saved from each rat brain for staining with thionine.

Receptor labeling procedure. Binding was performed by incuhating slide-mounted sections at room temperature for $30 \mathrm{~min}$ with $\left[{ }^{3} \mathrm{H}\right] \mathrm{NBI}$ $(0.7 \mathrm{nM})$ in $50 \mathrm{mM}$ Tris- $\mathrm{HCl}(\mathrm{pH} 7.4)$ with or without other compounds of interest. Following incubation with $\left[{ }^{3} \mathrm{H}\right] \mathrm{NBI}$, the tissue section was washed in buffer alone at $0^{\circ} \mathrm{C}$ (three 1-min washes). Blank values were generated by adding an excess of NBI (20 $\mu \mathrm{M}$ final concentration). In the preliminary biochemical studies the lissue sections were wiped off the slide with a Whatman GF-B filter and placed in a scintillation vial with $15 \mathrm{ml}$ of Ready-Solv (Beckman). The radioactivity was measured in a scintillation counter (Searle) using a single-channel ratio for calculation of the efficiency.

Autoradiographic studies. For the autoradiographic studies sets of 120 sections from four different animals were incubated under optimized conditions using $0.7 \mathrm{nM}\left[{ }^{3} \mathrm{H}\right] \mathrm{NBI}$ for $30 \mathrm{~min}$. Nonspecific binding was obtained on adjacent sections by adding to the incubation media an excess of NBI. Following the incubation and the rinses the sections were placed on racks and dried under a stream of cold, filtered, dry air 


\section{SATURATION ISOTHERM OF [3H]NBI BINDING TO SLIDE MOUNTED RAT BRAIN SLICES}

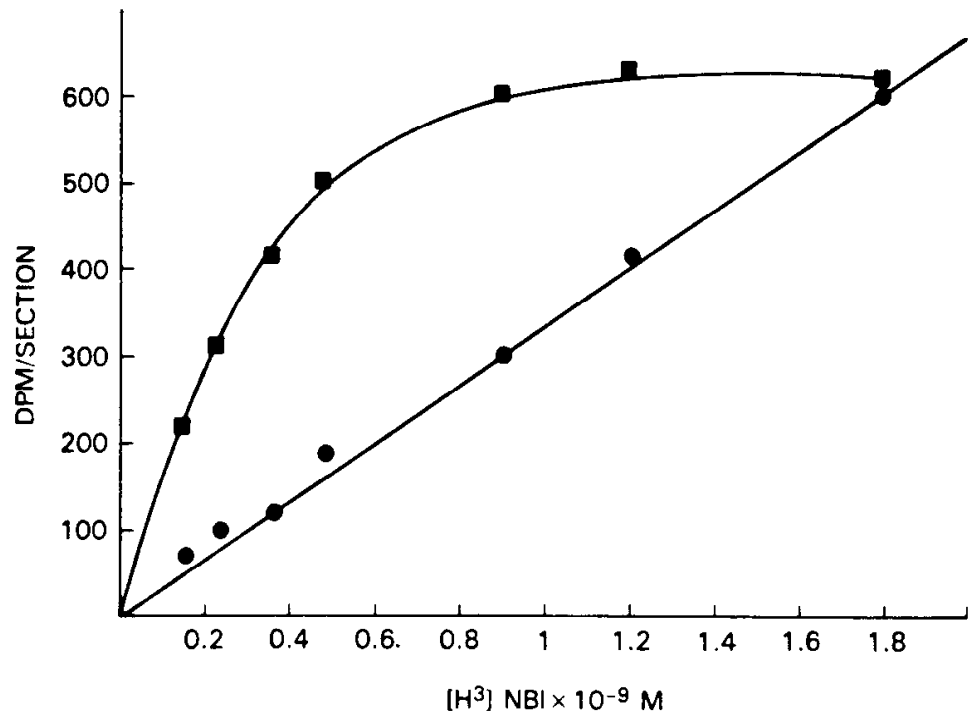

Figure 1. Saturation isotherm and Scatchard analysis of $\left[{ }^{3} \mathrm{H}\right] \mathrm{NBI}$ binding to slide-mounted rat brain slices. A representative experiment is shown. The calculated parameters are $K_{\mathrm{D}}=0.39 \mathrm{nM}$ and $B_{\max }=150 \mathrm{fmol} / \mathrm{mg}$ of protein. This experiment was repeated twice with very similar results.

\section{SCATCHARD ANALYSIS OF [3H]NBI BINDING TO SLIDE MOUNTED RAT BRAIN SLICES}

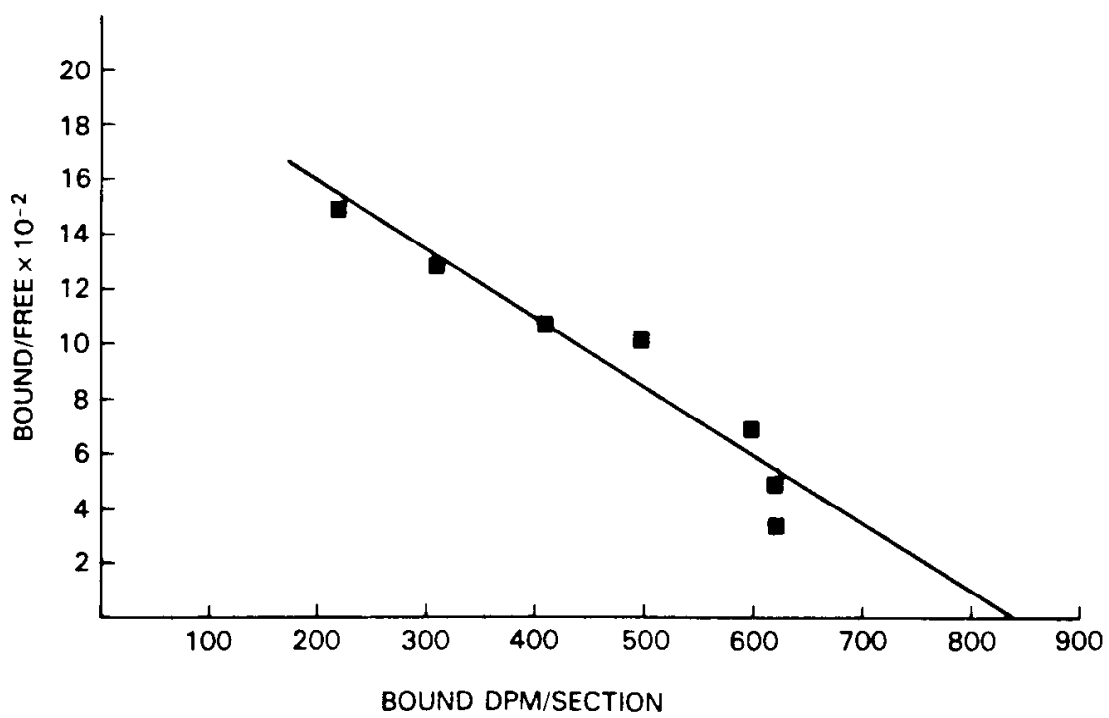

and then placed in apposition to LKB Ultrofilm in a light-proof cassette (Wolf Picker). After 9 weeks of exposure, the films were developed with Kodak D-19 (4 min at $22^{\circ} \mathrm{C}$ ), then rinsed in running water for 30 min, cleaned with deionized water, and dried at room temperature. The autoradiograms were screened and optical density measurements were performed using a computer image-processing system previously described (Goochee et al., 1980). The identification of the brain microregions was made with the aid of adjacent stained sections, using as reference the atlases of Paxinos and Watson (1982) and Koenig and Klippel (1963). For further comparison, one set of rat brain sections was incubated with $\left[{ }^{3} \mathrm{H}\right]$ cyclohexyladenosine, using conditions previously described (Lewis et al., 1981).

\section{Results}

Biochemical properties of $\left[{ }^{3} H\right] N B I$ binding to brain slices. $\left[{ }^{3} \mathrm{H}\right] \mathrm{NBI}$ binding to rat brain sections is saturable (Fig. 1).
Nonspecific binding represents $30 \%$ of the total binding for $\left[{ }^{3} \mathrm{H}\right] \mathrm{NBI}$ concentrations below $1 \mathrm{~nm}$.

Scatchard analysis of the binding shows a dissociation constant $\left(K_{\mathrm{d}}\right)$ of $0.39 \mathrm{nM}$ and a maximal number of sites $\left(B_{\max }\right)$ of approximately $150 \mathrm{fmol} / \mathrm{mg}$ of protein (Fig. 1). These values are comparable to those observed in rat brain homogenates (Marangos et al., 1982). To ensure that the binding in brain sections involved the same site that had been characterized previously in brain membranes, we evaluated the displacement of $\left[{ }^{3} \mathrm{H}\right] \mathrm{NBI}$ by NBI, $N^{6}$-cyclohexyladenosine (CHA), a specific ligand of the adenosine receptor, and dipyridamole. The $\mathrm{IC}_{50}$ values (data not shown) obtained were $2 \mathrm{nM}$ for NBI, $6 \mu \mathrm{M}$ for dipyridamole, and $15 \mu \mathrm{M}$ for $\mathrm{CHA}$, all of which are comparable to those observed with membrane preparations (Marangos et al., 1982). The binding to brain sections reached an equilibrium 
TABLE I

Regional distribution of $\left[{ }^{3} \mathrm{H}\right] \mathrm{NBI}$ binding in rat brain

Mean optical densities were measured by outlining each anatomical structure with the image processor; stained sections were used comparatively for precise localization. The optical density values are averages obtained for three to five measurements of the same structure on contiguous sections of each animal's brain. The value of the SEM was $\leq 0.01$. The mean optical density of the film background was .08 . For hippocampus and dentate gyrus the optical density reported is the mean value of all layers.

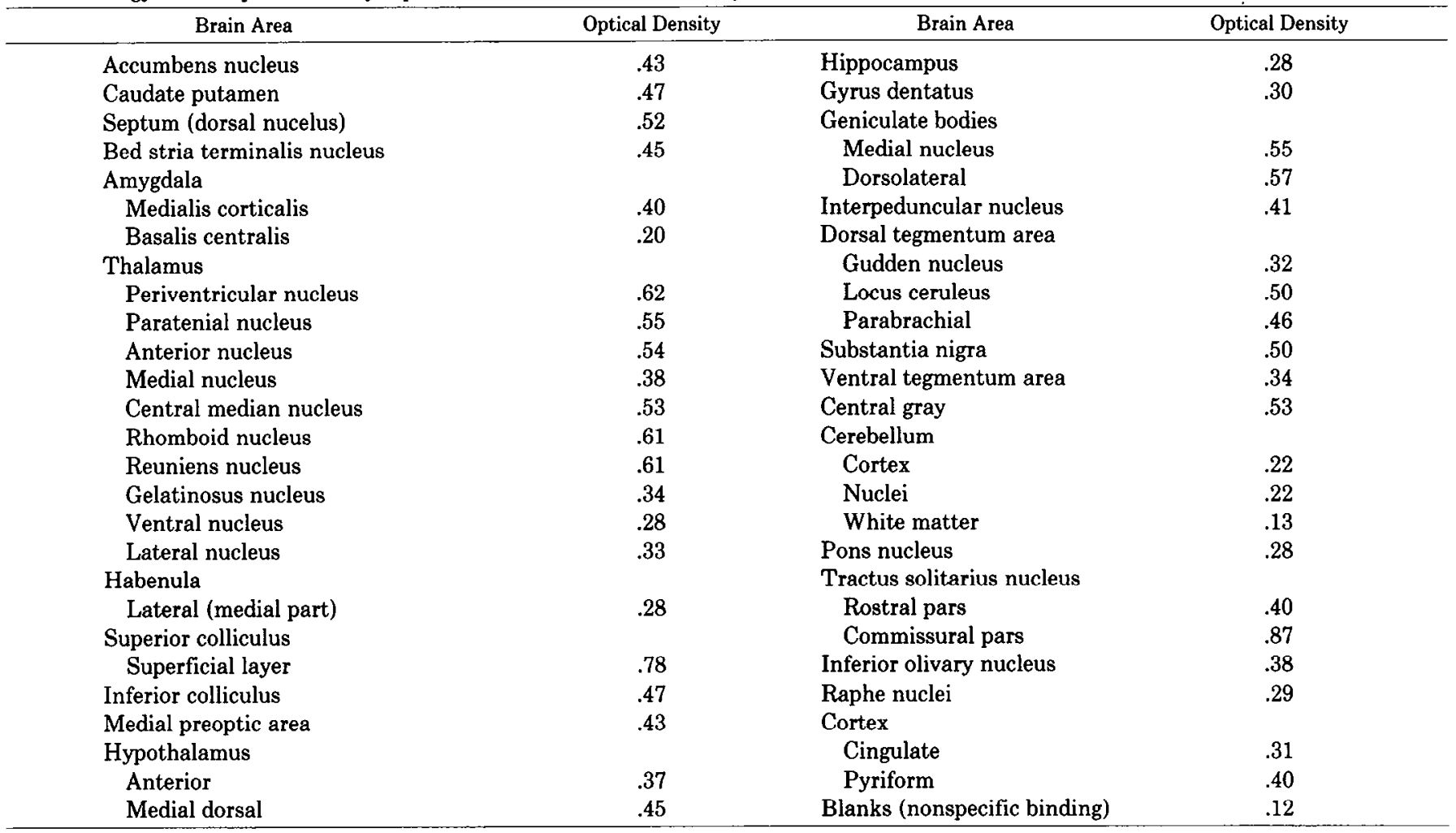

after $20 \mathrm{~min}$, and more than $70 \%$ of the initial specific binding remained after a $20-\mathrm{min}$ wash in $500 \mathrm{ml}$ of $50 \mathrm{mM}$ Tris buffer (data not shown).

Regional distribution of $\left[{ }^{3} \mathrm{H}\right] N B I$-binding sites. The optical densities of the various brain areas measured are summarized in Table I. In the forebrain several structures show high NBI binding density, among which is the pyriform cortex. All other cortical areas show a very low density of binding sites with a more elevated level in layer IV, with the exception of cingulate cortex which shows a moderate to low density of sites (Fig. 2, $B$ and $D$ ). Caudate putamen and nucleus accumbens show a homogeneous high density. In the septum only the dorsal part of the lateral septum displays a high density of binding sites (Fig. $3 a$ ). In the amygdala, moderate optical densities are observed in medialis and cortical nuclei. The hippocampus shows a very low density of sites (Fig. $2 D$ ). In the midbrain, high densities are observed in the superficial layer of the superior colliculus, the central gray matter in the substantia nigra, the dorsal tegmentum area, where both nuclei parabrachialis superior and inferior and locus ceruleus show higher density than does the nucleus tegmentum dorsalis of Gudden (Figs. 3 and 4). In the hindbrain the localization of NBI-binding sites is very heterogenous. The nucleus tractus solitarius shows the highest density of sites in the whole brain. A very high density of sites is observed in the commissural part of that nucleus, the rostral part shows lower density. (Fig. 5, $a$ and $b$ ). The substantia gelatinosa of the nucleus of the spinal tract of the trigemini nerve also shows a high density of NBI sites (Fig. $5 b$ ). Moderate levels of binding are observed in the superior olivary complex (Fig. 5b). The cerebellum has a low homogeneous level of sites (Fig. $2 F$ ). All white matter areas seem to have a negligable amount of NBI-binding sites.

\section{Discussion}

In this study we show that the binding of $\left[{ }^{3} \mathrm{H}\right] \mathrm{NBI}$ to brain tissue sections has characteristics of the adenosine uptake site in brain homogenates (Marangos et al., 1982). The binding is saturable with kinetic constants compatible to those observed in homogenate preparations and shows comparable pharmacological properties. The autoradiographic study shows a heterogeneous distribution of adenosine uptake sites throughout. the brain that is basically consistent with the regional distribution observed in brain homogenate studies (Marangos et al., 1982). In order to evaluate the meaning of this distribution, we have compared the localization of the adenosine uptake site with the localization of the adenosine A-1 receptor (Table II). For this comparison we have used previous reports describing the anatomical distribution of adenosine receptor (Lewis et al., 1981; Goodman and Snyder, 1982), and we have performed an autoradiographic study on a set of sections adjacent to those used for $\left[{ }^{3} \mathrm{H}\right] \mathrm{NBI}$ binding. The results of this comparison are summarized in Table I and illustrated in Figure 2. Some structures that show a very high density of both sites are the caudate putamen, nucleus accumbens, dorsal septum, pyriform cortex, substantia nigra, superficial layer of the superior colliculus, and substantia gelatinosa of the nucleus of the spinal tract of the trigeminal nerve. In the thalamus both the adenosine receptor and the adenosine uptake site are also present at high densities, but some differences exist in their relative distribution among the different thalamic nuclei. Higher adenosine receptor densities are observed in the anterior nuclei, gelatinosa, and medial nuclei. Higher levels of adenosine uptake sites are seen in paraventricular nucleus and the rhomboid and reuniens nuclei (see Fig. 2). In contrast, some structures which possess a very high density of adenosine receptors show low amounts of aden- 

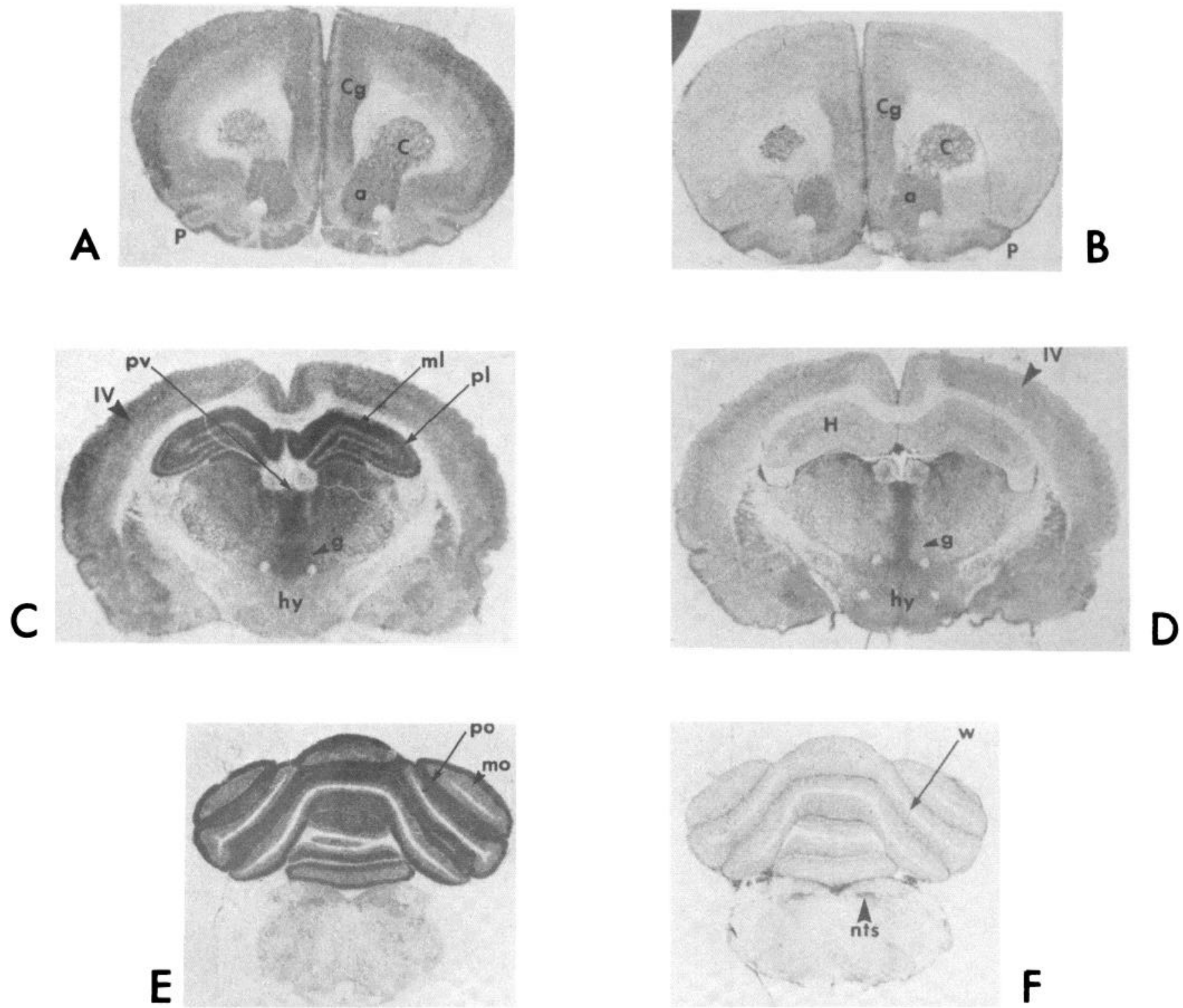

Figure 2. Comparison of the distribution of $\left[{ }^{3} \mathrm{H}\right] \mathrm{NBI}-$ binding sites (right side, section BDF) and $\left[{ }^{3} \mathrm{H}\right] \mathrm{CHA}$ receptor (left side, section ACE) in some areas of the rat brain. $A$ and $B, A 9820 \mathrm{u}$ (Koenig and Klippel, 1963), show a similar relative distribution of the two receptors in pyriform cortex $(P)$, nucleus accumbens $(a)$, and caudate nucleus $(C)$, the level of $\left[{ }^{3} \mathrm{H}\right] \mathrm{NBI}$ sites is relatively low in the cortical area except in the pyriform and cingulate $(\mathrm{Cg})$ cortex. The fourth layer of the cortex $(I V)$ shows a higher density of sites for both ligands. The comparison between $C$ and $D$ shows the difference of distribution of the two sites in hippocampus $(H)$ and hypothalamus $(h y)$. The characteristic layer distribution of $\left[{ }^{3} \mathrm{H}\right]$ CHA receptor (high density in molecular layer $(m l)$, lower density in pyramidal layer $(p l)$ ) is replaced by a low homogeneous density in the case of the uptake site. For both sites, the thalamus shows a rather high density. Some discrepancies can be observed in the nucleus gelatinosus ( $g$ ) (relatively lower $\left[{ }^{3} \mathrm{H}\right] \mathrm{NBI}$ site density) and in the paraventricular nucleus ( $\left.p v\right)$ (relatively higher $\left[{ }^{3} \mathrm{H}\right] \mathrm{NBI}$ receptor density). $E$ and $F$, Bregma$12.8 \mathrm{~mm}$ (Paxinos and Watson, 1982), illustrate the different relative distributions of the two sites in the cerebellum. The low homogeneous density of $\left[{ }^{3} \mathrm{H}\right] \mathrm{NBI}$ sites (with the exception of white matter $(w)$, which is devoid of receptor) contrasts with the heterogeneous pattern of $\left[{ }^{3} \mathrm{H}\right]$ $\mathrm{CHA}$ receptor distribution (high density in polymorphic layer $(p o)$, lower density in molecular layer $(m o)$ ). In $F$, the moderate $\left.{ }^{3} \mathrm{H}\right] \mathrm{NBI}$ site density of the rostral part of the nucleus of tractus solitarius $(n t s)$ is observed. The densification observed in the fourth ventricle in $F$ corresponds to the binding of $\left[{ }^{3} \mathrm{H}\right] \mathrm{NBI}$ to red blood cells trapped in that cavity.

osine uptake sites. In the cerebellum and the hippocampus, where adenosine receptors are present at high densities on specific layers, the uptake sites show homogeneous low levels without differences between the different layers (see Fig. 2). The same disparity is observed in the amygdala complex, where only the central nucleus possesses adenosine receptors, but the adenosine uptake site is present in high amounts in both the cortical and medial nuclei.

The relative density of both the receptor and uptake site could represent one index of functional activity of the adenosine system, high activity being associated with high number of adenosine receptor and uptake sites. In light of this, an active adenosinergic system might be expected in caudate putamen, nucleus accumbens, pyriform cortex, septum, substantia nigra, superior colliculus (superficial layer), and substantia gelatinosa of the trigeminal nerve. In contrast, cerebellum and hippocampus, although rich in the adenosine receptor, might display a lower level of adenosinergic function. Further physiological studies are of course required to substantiate these speculations. A third group of structures containing a high density of the adenosine uptake site with very low levels of adenosine receptor also exists. In this group are found the nucleus of the tractus 

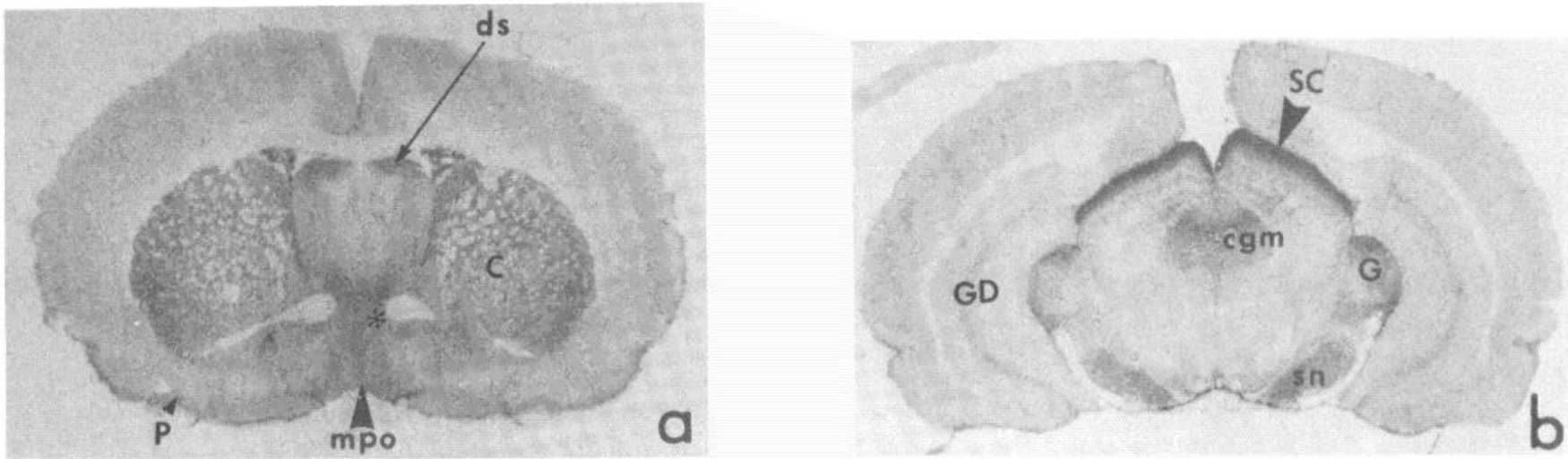

Figure 3. Distribution of $\left[{ }^{3} \mathrm{H}\right] \mathrm{NBI}$-binding sites in various brain areas. $a$ is section A7474 $\mu$ (Koenig and Klippel, 1963). Moderate to high densities of receptor are observed in the dorsal part of the lateral septum $(d s)$, in the caudate putamen $(c)$, in the nucleus of stria terminalis $\left({ }^{*}\right)$, in the medial preoptic area $(m p o)$, and in the pyriform cortex $(P)$. $b$ is one intermediate section between -5.3 and $-5.8 \mathrm{~mm}$ bregma (Paxinos and Watson, 1982). The superficial layer of the superior colliculus $(S C)$ shows a very high receptor density. The substantia nigra ( $s n)$, the central gray matter $(\mathrm{cgm})$ (specifically, its dorsal part), and the dorsal part of the geniculate body $(G)$ show moderate to high density of $\left[{ }^{3} \mathrm{H}\right] \mathrm{NBI}$ sites. Only a low $\left[{ }^{3} \mathrm{H}\right] \mathrm{NBI}$ receptor density is present in gyrus dentatus $(G D)$.
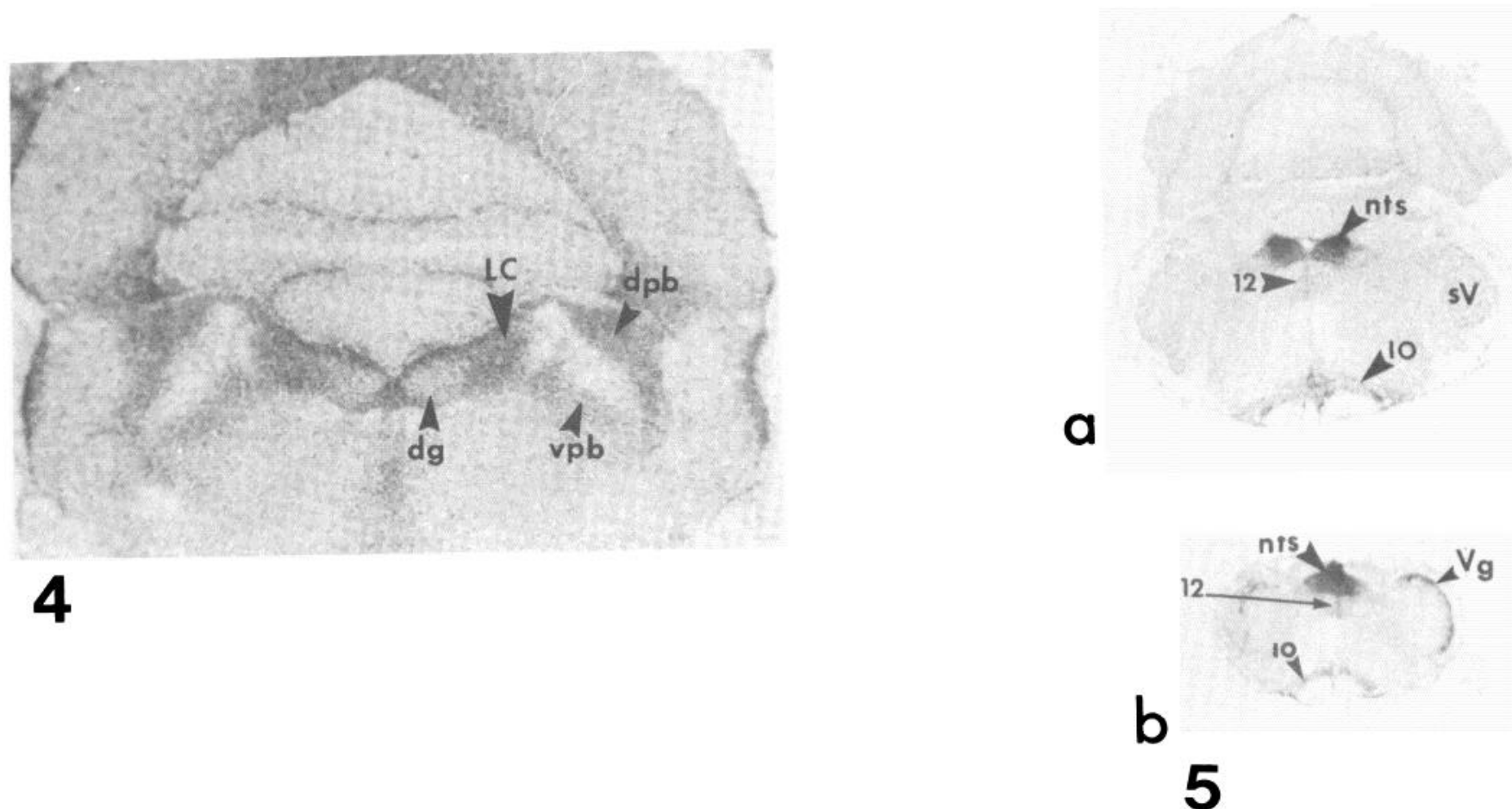

Figure 4. $\left[{ }^{3} \mathrm{H}\right] \mathrm{NBI}$-binding site distribution in the dorsal tegmentum area of the rat brain. The locus ceruleus $(L C)$ shows higher $\left[{ }^{3} \mathrm{H}\right] \mathrm{NBI}$ site density than do the surrounding nuclei: nucleus dorsal tegmentum of Gudden $(d g)$, nucleus parabrachialis dorsal $(d p b)$ and ventral $(v p b)$.

Figure 5. $\left[{ }^{3} \mathrm{H}\right]$ NBI site distribution in the rat brainstem. In both $a$ and $b$ appear the very high density $\left[{ }^{3} \mathrm{H}\right] \mathrm{NBI}$ site localization of the nucleus of tractus solitarius ( $n t s)$ in its medial and then rostral part. A low receptor density is present in the inferior olivary complex (io). In $b$, high site density is observed on the substantia gelatinosa $(V g)$ of the nucleus of the spinal tract of the trigeminal nerve $(s V)$. The hypoglossal nucleus (12) has a low but significant level of $\left[{ }^{3} \mathrm{H}\right] \mathrm{NBI}$ receptor.

solitarius, the central gray nuclei, the hypothalamus (in its dorsomedial part), and the dorsal tegmentum. The uptake site in these areas could be related to the presence of an adenosine receptor not susceptible to $\left[{ }^{3} \mathrm{H}\right] \mathrm{CHA}$ binding. Since $\left[{ }^{3} \mathrm{H}\right] \mathrm{CHA}$ probably binds selectively to A-1 adenosine receptors, it is possible that these areas contain A-2 receptors. Previously, we have shown (Marangos et al., 1983) that the adenosine antagonist $\left[{ }^{3} \mathrm{H}\right]$ diethylphenylxanthine has binding properties different from $\left[{ }^{3} \mathrm{H}\right] \mathrm{CHA}$ has, with a higher number of sites (possibly reflecting its ability to interact with both A-1 and A-2 receptors). It is, therefore, possible that $\left[{ }^{3} \mathrm{H}\right] \mathrm{CHA}$ is not labeling all adenosine receptors in brain.
It is also possible that the $\left[{ }^{3} \mathrm{H}\right] \mathrm{NBI}$-binding sites seen in some brain areas function to take up other nucleosides, since this has been shown to be possible (Hammond and Clanachan, 1983). However, it has been shown that the adenosine uptake site does favor adenosine (Bender, 1980).

The presence of a very high density of adenosine uptake sites in the nucleus of the tractus solitarius could be related to some central effect of adenosine. This nucleus, particularly its commissural part, represents the main central control structure of blood pressure. The closely related nucleus parasolitarius is also involved in the control of respiration (Palkovits and $\mathrm{Za}$ - 
TABLE II

Comparative regional distribution of adenosine receptor and adenosine uptake site

The table has been established using the regional distribution of the adenosine receptor found by Lewis et al. (1981) and Goodman and Snyder (1982), the $\left[{ }^{3} \mathrm{H}\right] \mathrm{CHA}$ data in this report, and the $\left[{ }^{3} \mathrm{H}\right] \mathrm{NBI}$ data decribed in this report.

\begin{tabular}{|c|c|c|}
\hline Brain Region & $\begin{array}{l}\text { Adenosine } \\
\text { Receptor }\end{array}$ & $\begin{array}{c}\text { Adenosine Uptake } \\
\text { Site } \\
\end{array}$ \\
\hline Pyriform cortex & high & high \\
\hline Caudate putamen & high & high \\
\hline Accumbens nucleus & high & high \\
\hline $\begin{array}{l}\text { Septum lateralis (pars } \\
\text { dorsalis) }\end{array}$ & high & high \\
\hline \multicolumn{3}{|l|}{ Thalamic nuclei } \\
\hline Paraventricular & moderate & very high \\
\hline Paratenial & high & high \\
\hline Rhomboid & moderate & high \\
\hline Reuniens & moderate & high \\
\hline Gelatinosus & very high & moderate to low \\
\hline Medial & light & moderate \\
\hline \multicolumn{3}{|l|}{ Amygdala } \\
\hline Central nucleus & moderate & very low \\
\hline Cortical nuclcus & absent & moderate \\
\hline Medial nucleus & absent & moderate \\
\hline Basal nucleus & absent & very low \\
\hline Hippocampus & high & low \\
\hline Dorsal tegmentum area & low & high \\
\hline $\begin{array}{l}\text { Superior colliculus (super- } \\
\text { ficial layer) }\end{array}$ & high & high \\
\hline Substantia nigra & high & high \\
\hline Central gray & low & high \\
\hline Geniculate body & high & moderate \\
\hline $\begin{array}{l}\text { Nucleus of the tractus so- } \\
\text { litarius }\end{array}$ & low & very high \\
\hline $\begin{array}{l}\text { Substantia gelatinosa of } \\
\text { nucleus of spinal tract } \\
\text { of trigeminal nerve }\end{array}$ & high & high \\
\hline \multicolumn{3}{|l|}{ Cercbellum } \\
\hline Granular layer & moderate & low \\
\hline Molecular layer & high & low \\
\hline
\end{tabular}

borsky, 1977). The fact that adenosine agonists have marked hypotensive effects and depress respiration (Hedner et al., 1982), coupled with the high density of the uptake site in the nucleus tractus solitarius, suggests that the hypotensive effects of adenosine are in part centrally mediated. This is also supported by the observation that phenylsulfotheophylline, an adenosine antagonist that does not cross the blood-brain barrier, does not fully reverse the hypotensive effect of adenosine agonists (unpublished observations).

It has been suggested recently that benzodiazepines (BZs) may act at the adenosine uptake site (Phillis et al., 1981; Hammond and Clanachan, 1982). The distributions of the BZ receptor (Young and Kuhar, 1980) and the adenosine uptake site show some similarities. Both sites are present in important amounts in certain structures such as the pyriform cortex, superior colliculus, central gray, substantia nigra, and the dorsal tegmentum, substantia gelatinosa of the trigeminal nerve. However, there are many discrepancies between the localization of $\mathrm{BZ}$ receptors and adenosine uptake sites. For instance, the cerebellum and the hippocampus show high densities of $\mathrm{BZ}$ receptors and very low density of adenosine uptake sites. The high densities of $\mathrm{BZ}$ receptor observed in frontal cortex are also not matched by adenosine uptake sites. In the septum, BZ receptors are concentrated in the nucleus medialis, whereas the uptake site is present only in the dorsal part of the septum.
The highest density of adenosine uptake site is in the pars commissuralis of the nucleus tractus solitarius. BZ receptors are only present in very low density in that area.

The adenosine uptake site is, therefore, highly localized in rodent brain with a regional distribution that is different from that of the adenosine receptor labeled by $\left[{ }^{3} \mathrm{H}\right] \mathrm{CHA}$ and the $\mathrm{BZ}$ rcceptor. It appears, therefore, that certain brain nuclei have a greater density of adenosine uptake sites, and it is possible that these areas may represent brain regions which contain adenosinergic neurons.

\section{References}

Arch, J. R. S., and E. A. Newsholme (1978) The control of the metabolism and the hormonal role of adenosine. Biochem. J. 174: 965-977.

Barberis, C., A. Minn, and J. Gayet (1981) Adenosine transport in guinea pig synaptosomes. J. Neurochem. 362: $347-354$.

Bender, A. S. (1980) The characterization of $\left[{ }^{3} \mathrm{H}\right]$ adenosine uptake into rat cerebral cortex synaptosomes. J. Neurochem. 35: 629-640.

Bruns, R. F., J. W. Daly, and S. H. Synder (1980) Adenosine receptor in brain membrane-Binding of $\mathrm{N}^{6}$-cyclohexyl $\left[{ }^{3} \mathrm{H}\right]$ adenosine and 1,3 diethyl-8-[ $\left.{ }^{3} \mathrm{H}\right]$ phenylxanthine. Proc. Natl. Acad. Sci. U. S. A. 77: $5547-5552$.

Cooper, D. M. F., C. Londos, and C. Rodber (1980) Adenosine receptor mediated inhibition of rat cerebral cortical adenylate cyclase by a GTP-dependent process. Mol. Pharmacol. 18: 598-601.

Daly, J. W. (1983) Role of ATP and adenosine receptors in physiological processes: Summary and prospectus. In Physiology and Pharmacology of Aderwsine Derivatives, J. W. Daly, Y. Kuroda, J. W. Phillis, H. Shimizu, and M. Ui, eds., pp. 275-290, Raven Press, New York.

Goochee, C., W. Rasband, and L. Sokoloff (1980) Computerized densitometry and color coding of $\left[{ }^{14} \mathrm{C}\right]$ deoxylglucose autoradiographs. Ann. Neurol. 7: 359-370.

Goodman, R. R., and S. H. Snyder (1982) Autoradiographic localization of adenosine receptors in rat brain using $\left[{ }^{3} \mathrm{H}\right]$ cyclohexyladenosine. J. Neurosci. 2: 1230-1241.

Hammond, J. R., and A. S. Clanachan (1982) Benzodiazepines inhibit the binding of nitrobenzylthioinosine, a nucleoside transport inhibitor, to CNS membranes. Br. J. Pharmacol. 76: 301.

Hammond, J. R., and A. S. Clanachan (1983) Distribution of nucleoside transport sites in guinea pig brain. J. Pharm. Pharmacol. 35: 117118.

Hedner, T., J. Hedner, P. Wessberg, and J. Honason (1982) Regulation of breathing in the rat: Indication for a role of central adenosine mechanism. Neurosci. Lett. 33: 147-151.

Herkenham, M., and C. B. Pert (1982) Light microscopic localization of brain opiate receptor: A general autoradiographic method which preserves tissue quality. J. Neurosci. 2: 1129-1149.

Jarvis, S. M., and J. D. Young (1980) Nucleoside transport in human and sheep erythrocytes: Evidence that nitrobenzylthioinosine binds specifically to functional nucleoside transport sites. Biochem. J. 190: 377-383.

Koenig, J. K., R. A. Klippel (1963) A Stereotaxic Atlas of the Forebrain and Lower Parts of the Brain Stem, Robert E. Krieger Publishing Co., Huntington, NY.

Kuroda, Y., and H. MacIlwain (1974) Uptake and release of $\left[{ }^{14} \mathrm{C}\right]$ adenosine derivatives at beds of mammalian cortical synaptosomes in a superfusion system. J. Neurochem. 22: 691-699.

Lewis, M. E., J. Patel, S. Moon edley, and P. J. Marangos (1981) Autoradiographic visualization of rat brain adenosine receptors using $N$-6-cyclohexyl [ $\left.{ }^{3} \mathrm{H}\right]$ adenosine. Eur. J. Pharmacol. 73: 109-110.

Marangos, P. J., J. Patel, R. Clark-Rosenberg, and A. M. Martino (1982) [ $\left.{ }^{3} \mathrm{H}\right]$ Nitrobenzylthioinosine binding as a probe for the study of adenosine uptake sites in the brain. J. Neurochem. 39: 184-191.

Marangos, P. J., J. Patel, A. M. Martino, M. Dilli, and J. -P. Boulenger (1983) Differential binding properties of adenosine receptor agonist and antagonists in brain. J. Neurochem. 41: 367-374.

Palkovits, M., and L. Zaborsky (1977) Neuroanatomy of central cardiovascular control. Nucleus tractus solitari: Afferent and efferent neuronal connections in relating to the barareceptor reflex area. Prog. Brain Res. 47: 9-34.

Patel, J., P. J. Marangos, J. Stivers, and F. K. Goodwin (1982) Characterization of adenosine receptors in the brain using $N^{6}$-cyclohexyl $\left[{ }^{3} \mathrm{H}\right]$ adenosine. Brain Res. 237: 203-214.

Paxinos, G., and C. Watson (1982) The Rat Brain in Stereotaxic Coordinates, Academic Press, Inc., New York.

Phillis, J. W., P. H. Wu, and A. G. Bender (1981) Inhibition of 
adenosine uptake into rat brain synaptosomes by the benzodiazepines. Gen. Pharmacol. 12: 67-70.

Pickard, M. A., and A. R. P. Paterson (1972) Use of 4-nitrobenzylthioinosine in the measurement of rates of nucleoside transport in human erythrocytes. Can. J. Biochem. 50: 839-840.

Pull, l., and $\mathrm{H}$. Macllwain (1974) Rat cerebral-cortex adenosine deaminase activity and its subcellular distribution. Biochem. J. 144: $37-41$.

Ribeiro, J. A. (1979) Purinergic modulation of transmitter release. J. Theor. Biol. 80: 259-270.
Shimizu, H., S. Tanaka, and T. Kodama (1972) Adenosine kinase of mammalian hrain: Partial purification and its role for the uptake of adenosine. J. Neurochem. 19: 687-698.

Van Calker, D., M. Muller, and B. Hamprecht (1979) Adenosine regulates two differents types of receptors, the accumulation of cyclic AMP in culture brain cells. J. Neurochem. 33: 999-1005.

Young, W. S., III, and M. J. Kuhar (1980) Radiohistochemical localization of benzodiazepine receptors in rat brain. J. Pharmacol. Exp. Ther. 212: 337-346. 